\title{
OM KULTURMINNETS LÄTTHET OCH TYNGD
}

Samhällsminnet byggs upp av de föreställningar, erfarenheter, förmågor, kunskaper och drömmar som delas av samhällsmedlemmarna och som finns i deras levande minne, styr deras beteende, attityder och reaktioner. Samhällsminnet lagras också i texter, materialiseras i byggenskap och ting. Varje människas kulturminne är unikt, delaktigheten i det gemensamma, spontant tillägnad, påtvingad eller förhandlad. Sällan är samhällsminnet homogent, ensartat, ens i små samhällen; det sönderfaller i delkulturer formade i ständigt utbyte mellan individuella och gemensamma minnen. Kulturminnet förlängs och fortlever mentalt och konkret som mångdimensionellt kulturarv. I verbal och visuell transkription kan det återuppsökas, erinras, återupptäckas i text- och bildarkiv, i de fysiska verklighetsspåren.

Lätt är det levande internaliserade kulturminnet, det bärs med självklarheten i det för-givet-tagna, men det är skört som livet. Det observerade, efterhärmade, översatt i reflexmässig motorik hjälper oss med vardagslivets rutiner och rumsliga förflyttningar - $\mathrm{i}$ hemmet, grannskapet, världen. I samhällets dagliga strömmar av trajektorier avtecknar sig kulturmönster. En kultur får urskiljbar gestalt.

Tyngd har det fysiska samhälleligt definierade och kostsamma kulturarv som förvaltas i museer och av kulturarvsinstitutioner. De fysiska objekten är stumma, făr ett språk bara i relation till levande subjekt. I musealiseringsprocessen vägs det materiella och immateriella samman. I det konkreta ska kulturminnets immateriella mervärde kunna avlyssnas och betraktas, trösta, ge insikter, kanske tjäna som riktningsgivare. Den antikvariska uppgiften: att kontinuerligt avläsa och filtrera verklighetsflödet, mäta de historiska förändringarna med Braudel-skala för att kunna gestalta ett meningsbärande kulturarv. Tingen får symbolisk dignitet genom sin laddning av minnen och berättelser. Antikvariens öde - att i den mångkulturella virvelvinden av kolliderande och konkurrerande verklighetsbilder notera och anamma det sedda med den dubbla känslan av förlamning och befrielse?

Hur kulturarvens batterier laddas - och urladdas - är ett centralt område för museologisk analys och eftertanke i detta nummer av tidskriften.

Vad händer i samband med politiska maktskiften när en verklighetsbild byts mot 
en annan? Marc Maure, som under de senaste åren gjort upprepade besök i Ryssland, belyser i den inledande texten regimskiftet i Sovjet och sammanbrottet av den stora berättelse som utgjort ram för samhällsminnet och grund för kulturarvet. Många museer har slagits ut, medan andra blivit viktiga platser för ny- och omtolkning av historien, nu även för en demokratisk samhällsdialog.

Svante Lindqvist visar vad som händer när den symboliska laddningen i kulturminnen försvagas eller förändras och deras materiella manifestationer "genom en outtalad kollektiv process" nästan omärkligt upplöses i samhällsglömska.

Att själva kulturarvet är en artefakt som skapas och omskapas över tid är ämnet för Mette Skougaards studie av hur de historiska interiörerna tillkommit i det danska nationalhistoriska museet Frederiksborg. Ulla Kallberg visar hur det maritimhistoriska kulturminnet, fullriggaren 'Suomen Joutsen' i Åbo, kommit att bli ett politiskt tvisteämne där den ultimata frågan ställs: "vem skapar, vem definierar kulturella betydelser och varför?"

Ewa Bergdahlhar läst två utredningar om industrisamhällets kulturarv. Där diskuteras en utvidgning av monumentbegreppet från att ha handlat om själva industrianläggningarna till att gälla industrisamhället - det samhällsminne som i kulturarvsdiskursen under 1900-talet övertar den dominerande roll som de areella näringarnas traditionsarv spelat. Hur ska dessa recenta kulturminnen beredas berättigat utrymme i institutionernas verksamhet?

I studiet av två vägprojekt som berör högt värderade kulturminnen visar Mattias Bäckström på de svårigheter kulturarvsinstitutionernas värderingar har att bli beaktade i jämförelse med dem som företräds av samhällsekonomins och naturmiljövårdens förespråkare - även om det gäller ett på Unescos världsarvslista upptaget hällristningsområde, eller ett norrländskt riksintresse för kulturmiljövården.

Ytterligare två uppsatser ryms i numret. Merethe Frøyland behandlar ingående kunskapsförmedlingen i museer och visar hur konstruktivistiska idéer från Jean Piaget, Lev Vygotskij och Howard Gardner på ett systematiskt sätt kan tas till vara i museernas pedagogiska verksamhet. Heléne Jonsson, från programmet för utställningsgestaltning vid Linköpings universitet, skriver om ljudets ofta förbisedda roll för en utställning.

Slutligen - på sid 143 presenteras vår renoverade hemsida: www.nordiskmuseologi.com 